\title{
Regulating desire in Russia
}

\section{Kondakov, Alexander}

Edward Elgar

2020-03-11

Kondakov , A 2020 , Regulating desire in Russia . in Research Handbook on Gender, Sexuality and the Law . Edward Elgar, Cheltenham , pp. 396-408 .

http://hdl.handle.net/10138/317865

submittedVersion

Downloaded from Helda, University of Helsinki institutional repository.

This is an electronic reprint of the original article.

This reprint may differ from the original in pagination and typographic detail.

Please cite the original version. 


\section{RESEARCH HANDBOOK ON GENDER, SEXUALITY AND THE LAW}

\section{Edited by Chris Ashford, Northumbria University and Alexander Maine, Leicester University, UK}

'An important intervention in the persistent question of how we can use the law for sexual liberation without being used by the law. This volume interrogates who "we" are across multiple identities, what law is or has been in numerous jurisdictions, and what sexual, gender, and human liberation might be in our lifetimes. Not beholden to any particular theoretical perspective or doctrinal imperative, this collection will serve as a vital springboard for researchers in sex, gender, and legal struggles.

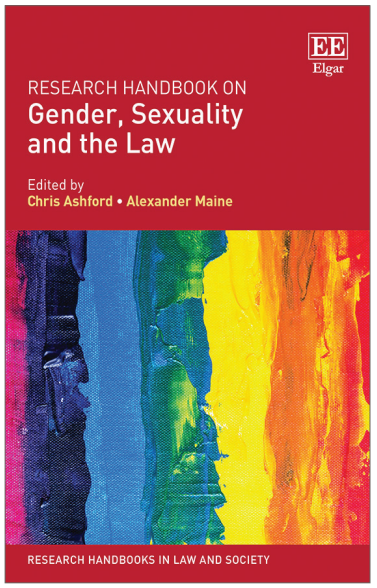

- Ruthann Robson, City University of New York, School of Law, US

'An important and timely collection that demonstrates the enduring value of gender and sexuality for legal and other scholars working across a wide range of issues. While revisiting and recasting gay rights and feminist insights, it also opens up and broadens the field - conceptually and geographically - and acknowledges and engages with debates, rather than attempting to resolve them. In true queer style it troubles boundaries and provides signposts rather than destinations.'

- Daniel Monk, Birkbeck, University of London, UK

'This book is a very useful resource for both students and academics wanting to consider where the field sits at this historical moment in which il/liberal states struggle with their own internal contradictions and the rise of populist movements. In the face of these forces, it charts paths for future socio-legal scholarship through theoretical and empirical engagement with activist struggles in the west and global south, foregrounding intersectionality in legal analysis around identity, lived experience, bodily autonomy, vulnerability and transgression.'

- Alex Sharpe, Keele University, UK

This innovative and thought-provoking Research Handbook explores not only current debates in the area of gender, sexuality and the law but also points the way for future socio-legal research and scholarship. It presents wide-ranging insights and debates from across the globe, including Africa, Asia, Eastern Europe and Australia, with contributions from leading scholars and activists alongside exciting emergent voices.

Chapters address a range of current arguments and issues, providing an enhanced theoretical framework and evolving understanding from a variety of feminist and queer perspectives. Relationship recognition debates and LGBT activism and scholarship are examined and discussed, as well as questions around bodily autonomy, kink identities, pornography and healthcare access rights. Research exploring the lived experiences of people facing challenges such as domestic violence, asylum, femicide and hate crime is also assessed.

This Research Handbook will be an invaluable resource for researchers and students in the fields of law, sexuality and gender, as well as family studies, sociology, media and cultural studies, and medicine. Activists will also benefit from its scholarly insight into key policy debates and future strategy.

2020 c 552 pp Hardback 978178811114 O £195.00 / \$290.00

eBook - Elgaronline

Research Handbooks in Law and Society series

\section{ORDER ONLINE}

Get $10 \%$ off hardbacks and $20 \%$ off paperbacks when you order on e-elgar.com

\section{ORDER BY EMAIL}

UK/RoW Orders

Email: sales@e-elgar.co.uk

N/S America Orders

Email: elgarsales@e-elgar.com

FOR MORE INFORMATION

OR TO ORDER A COPY OF OUR CATALOGUE:

UK/RoW

Email: info@e-elgar.co.uk

(N/S America)

Email: elgarinfo@e-elgar.com

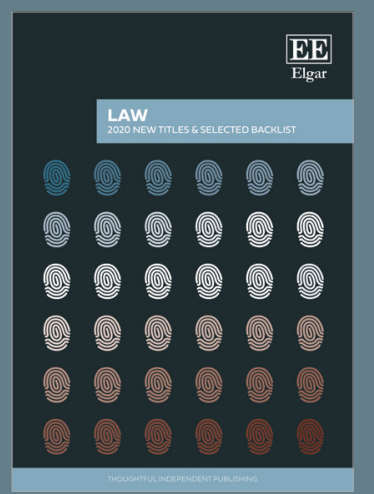

FOLLOW US

@Elgar_Law

\section{EE Elgar blog}

The Elgarblog covers the latest issues in economics, law, business \& management and the social sciences. Visit the blog for articles, insightful debate, interviews with influential scholars and tips for getting published.

www.elgar.blog

Edward Elgar monographs and handbooks are available as ebooks at a paperback price on Google Play, ebooks.com and other ebook vendors. Our ebooks are published simultaneously with the print version and are typically priced at c $£ 22.00 / c \$ 31.00$ for a monograph.

\section{Elgaronline}

